\title{
The half-life of truth in medicine regarding the Covid-19 disease
}

\author{
Caroline Bastid and Jean Louis Frossard* \\ Service of Gastroenterology and Hepatology, Geneva University Hospitals, Switzerland
}

After successfully controlling the first surge of infection and death brought on by the Sars-Cov 2 virus, there is currently no doubt about the worldwide occurrence of a second wave of COVID-19 disease. In Europe, several countries are reporting more daily Covid-19 cases than they did during the first wave in March, although the higher numbers may be due to more people being tested [1]; hospitals are currently overwhelmed.

It is now time for reflection. Indeed, the time has come to look behind us with humility and consider the real benefits and true lies that have been reported in the past six months regarding the epidemiology and therapy of the disease, facts that have been conveyed daily by the medical community to our population. The question raised by this platform is not only to challenge the trust we might have in doctors, who sometimes are in search of public recognition, but also to question the very opposite advices and debated therapies proposed to Sars-Cov 2 infected patients [2,3]. Moreover, some authors surprisingly published only results assessing virologic efficacy instead of clinical improvement [4].

If we adopt a positive attitude, one can easily say that medicine has dealt with an abrupt onset of an infectious disease that nobody was able to predict, and that tremendous increase in knowledge has been gained since January 2020 (Figure 1). However, substantial issues remain uncertain when considering the predominant route of viral transmission or the true effectiveness of medical therapies reported since the outbreak has begun. It is indeed surprising that even as of today, scientific experts are still debating whether viral airborne transmission contributes to the severity of the pandemic, although

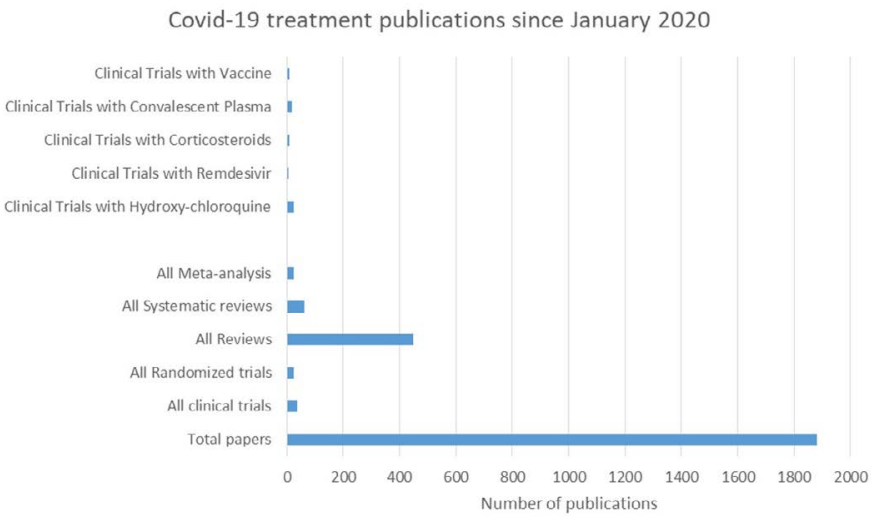

Figure 1. The studies were identified from PubMed. The search was conducted to include human studies published in English language from 2020/01/01 to 2020/11/01. The search terms included COVID-19, coronavirus disease-2019, treatment, hydroxychloroquine, remdesivir, corticosteroids, convalescent plasma and vaccine valuable experimental and clinical papers have been recently published on this specific point. In the same line, it is unbelievable to still hear some scientists claiming that face masks may only participate to help prevent the disease whereas hard data do exist, while N95 or similar respirators have been recently shown to be superior than disposable surgical masks [5].

Hydroxychloroquine has also been a matter of ample debate. While some clusters of doctors in France still claim that this medication effectively decreases disease morbidity and mortality $[2,3]$ they refuse to consider the negative results of larger randomized controlled studies [3]. These doctors embarrass themselves and all scientists worldwide whose work should only rely on proven facts. Moreover, it would be tempting to speculate that some malicious doctors or even pharmaceutical companies could have some financial interest in promoting therapies of uncertain efficacy. Above all, it is also surprising to note that a number of drugs either alone or in combination have been administered while their safety and effectiveness were still being questioned [6]. Even worse were the retracted Surgisphere papers from prestigious Journals after a Guardian investigation found inconsistencies in the data. Even if we are facing a huge and unpredictable potential human disaster, elemental rules of safety should not be discarded so easily. Finally, it is very disturbing to watch daily television programs or read newspapers where so many interviewed doctors are behaving like self-proclaimed, well-educated epidemiologists or infectious disease experts when they in fact have no such background or training. It is an appeal for scientists to only convey evidenced based facts instead of true lies to our world.

\section{Conflicts of interest}

Disclosure of all financial associations or other possible conflicts of interest: we have nothing to disclose.

\section{References}

1. Gisanddata.maps.arcgis.com/apps/opsdashboard/index.html.

2. Gautret P, Lagier J, Parola P (2020) Hydroxychloroquine and azithromycine as a treatment of Covid-19: results of an open-label nonrandomized clinical trial. Int $J$ Antimicrob Agents 56: 105949. [Crossref]

3. Tang W, Cao Z, Han M (2020) Hydroxychloroquine in patients with mainly mild to moderate coronavirus disease 2019: open label, randomised controlled trial. BMJ 369 : m1849 [Crossref]

${ }^{*}$ Correspondence to: Jean Louis Frossard, MD, Service de Gastroentérologie et Hépatologie, Geneva University Hospital, 4 rue Gabrielle-Perret-Gentil, 1211 Genève 14, Switzerland, E-mail: jean-louis.frossard@hcuge.ch

Received: October 25, 2020; Accepted: October 29, 2020; Published: November 02,2020 
4. Nakrem Lyngbakken M, Berdal J, Eskesen A (2020) A pragmatic randomized controlled trial reports lack of efficacy of hydroxychloroquine on coronavirus disease 2019 viral kinetics. Nat Commun 11: 5284. [Crossref]

5. Chu D, A Akl E, Duda S (2020) Physical distancing, face masks, and eye protection to prevent person-to-person transmission of SARS-Cov-2 and COVID-19: a systematic review and meta-analysis. Lancet 395: 1973-1987. [Crossref]
6. Ayele Mega T, Mulugeta Feyissa T, Dessalegn Bosho D, Kumela Goro K, Zeleke Negera G, et al. (2020) The Outcome of Hydroxychloroquine in Patients Treated for COVID-19: Systematic review and Meta-Analysis. Can Respir J.

Copyright: (C2020 Bastid C. This is an open-access article distributed under the terms of the Creative Commons Attribution License, which permits unrestricted use, distribution, and reproduction in any medium, provided the original author and source are credited. 